\title{
Branchial rickettsia-like infection associated with clam Venerupis rhomboides mortality
}

\author{
Antonio Villalba ${ }^{1, *}$, María J. Carballal ${ }^{1}$, Carmen López ${ }^{1}$, Azucena Cabada ${ }^{2}$, \\ Laura Corral ${ }^{3}$, Carlos Azevedo ${ }^{3}$ \\ ${ }^{1}$ Centro de Investigacións Mariñas, Consellería de Pesca, Marisqueo e Acuicultura, Aptdo. 13, E-36620 Vilanova de Arousa, Spain \\ ${ }^{2}$ Delegación Comarcal de Riveira, Consellería de Pesca, Marisqueo e Acuicultura, E-15960 Riveira, Spain \\ ${ }^{3}$ Departamento de Biologia Celular, Instituto de Ciências Biomédicas de Abel Salazar, Universidade do Porto, \\ P-4050 Porto, Portugal
}

\begin{abstract}
A histopathological survey was performed to search for the cause of high mortality of the clam Venerupis rhomboides (Pennant) in exploited beds of the Ensenada de Riveira (Ría de Arousa, Galicia, NW Spain). V. rhomboides from 2 beds affected by high mortality, Airós and Coroso, and a 3rd non-affected bed. Agudos, were sampled in spring and autumn of 1996. In addition, clams of the species Venerupis pullastra, with unnoticeable mortality, were taken from Airós during autumn sampling. According to prevalence, infection intensity and associated histopathological signs, a branchial rickettsia-like organism was the only pathogen that could be tentatively blamed for the mortality. Spherical to elongated intracytoplasmic rickettsia-like colonies up to $25 \mu \mathrm{m}$ in length were observed at the base of gill filaments of the clams. Transmission electron microscopy study permitted identification of the micro-organisms in the colonies as rickettsia-like. Individual prokaryotes measured about 0.5 to $0.8 \mu \mathrm{m}$ in diameter and up to $3 \mu \mathrm{m}$ in length. The infection process resulted in extreme hypertrophy and lysis of host epithelial cells. Infection intensity was rated for each clam and comparison among highmortality-affected and non-affected populations indicated the branchial rickettsia-like infection as the probable cause of the high mortality.
\end{abstract}

KEY WORDS: Venerupis rhomboides - Parasites - Rickettsia-like organisms - Histopathology - Ultrastructure

\section{INTRODUCTION}

Prokaryotes resembling Rickettsiae in terms of their ultrastructure and intracellular localisation have been reported from different bivalve species, mainly located in the hosts' digestive and branchial epithelia (Harshbarger et al. 1977, Comps 1983, Fries \& Grant 1991). Effects on the host were found to be very mildly detrimental or undetectable and were restricted to degeneration of the infected cell. However, branchial rickettsia-like infections have been occasionally associated with important mortalities in bivalve populations (Gulka \& Chang 1984, Elston 1986, Le Gall et al. 1988, Norton et al. 1993).

\footnotetext{
•E-mail: villalba@cimacoron.org
}

High mortality in exploited beds of banded carpetshell clam Venerupis rhomboides (Pennant) in the Ensenada de Riveira (Ría de Arousa, Galicia, NW Spain) was reported by fishermen in March 1996 after they found a high number of empty shells. A survey was conducted to investigate the mortality and to search for its cause. Mortality-affected and non-affected beds were sampled in spring and late summer of 1996. Various symbionts were detected in the clams, but according to prevalence, infection intensity and associated histopathological signs, a branchial rickettsia-like organism was the only pathogen that could be tentatively blamed for the mortality among all the parasites found.

This article presents the results of the survey, with emphasis on the morphology, pathogenesis and involvement of the branchial rickettsia-like organism in clam mortality. 


\section{MATERIALS AND METHODS}

Sampling methods. The Ensenada de Riveira is an inlet located on the northern side of the outer zone of the Ría de Arousa (Galicia, NW Spain) (Fig. 1). Urban effluents from the town of Riveira, and waste from its trading and fishing port, constitute the major sources of pollution. The subtidal zone of this inlet supports a commercial fishery of 2 clam species, the banded carpet-shell Venerupis rhomboides and the pullet carpetshell Venerupis pullastra (Montagu). In April 1996, samples of $V$. rhomboides were taken from 2 beds, Coroso and Airós, affected (according to fishermen) by mortality and from a third, non-affected bed, Agudos, which was used as reference. The sample from Airos included seed and adults, whereas only adults were taken in the samples from the 2 other beds. In September 1996, the 3 beds were sampled again. At this time, a sample of $V$. pullastra was taken from Airós as another reference because, according to fishermen, no mortality was observed in this species despite the fact that it shares the biotope with $V$. rhomboides.

Bed sampling involved trawling a clam dredge by hand from a small boat and taking each clam retained by the dredge mesh. Mortality was estimated by the percentage of recent empty shells in the samples. Only those empty shells with 2 valves joined by elastic ligament were considered. From each sampled bed, 25 clams were randomly chosen and processed for analysis of pathological condition. These clams were shucked and a gill lamella was excised from every specimen and processed according to the Ray (1966) method for detection of Perkinsus-like parasites, which based on incubation of bivalve tissue in fluid thioglycollate medium (FTM). In addition, an approximately $5 \mathrm{~mm}$ thick section of meat containing gills, foot and viscerai mass was fixed in Davidson's solution and embedded in paraffin; $5 \mu \mathrm{m}$ thick sections were stained with Harris' hematoxylin and eosin (HHE) and examined under light microscopy (LM) for disease diagnosis. Some Venerupis rhomboides from Coroso were processed for transmission electron microscopy (TEM) study: small fragments of gill were fixed in $2.5 \%$ glutaraldehyde in $0.2 \mathrm{M}$ cacodylate buffer at $\mathrm{pH} 7.6$ for 2 h at $4^{\circ} \mathrm{C}$, washed for $2 \mathrm{~h}$ at $4^{\circ} \mathrm{C}$ in the same buffer and postfixed in buffered $2 \%$ osmium tetroxide for $2 \mathrm{~h}$ at $4^{\circ} \mathrm{C}$. The fragments were dehydrated through a graded series of ethanol and embedded in Epon. Semithin sections for LM were stained with toluidine-Azur II. Ultrathin sections were double stained with uranyl acetate and lead citrate and observed in a JEOL 100 CXII TEM operated at $60 \mathrm{kV}$.
Rating of infection intensity. The intensity of infection by the branchial rickettsia in each clam was rated according to the mean number of rickettsia-like colonies per section of gill plica. The mean was estimated after counting the number of colonies occurring in 10 of the gill plica present in a histological section. The intensity of infection by a Perkinsus-like organism which enlarged in FTM was rated using a scale similar to that described by Mackin (1962), from uninfected (0) to heavy (5).

Statistics. Differences in intensity of infection by the branchial rickettsia among samples were analysed by a Kruskal-Wallis test followed by paired comparisons using the Mann-Whitney tests. MINITAB Statistical software was used for this purpose.

\section{RESULTS}

\section{Mortality}

Mortality recorded in Venerupis rhomboides populations of Coroso and Airós (both adults and seed) was higher at both sampling times than in samples from populations used as a reference (Table 1).

\section{Incubation in FTM}

Typical dark (blue-black and green-black) spheres were observed by light microscopy after the pieces of gill which had been incubated in FTM were flooded with Lugol's, thus suggesting infection by a Perkinsuslike parasite. A total of 43 cases of infection were detected, of which 41 corresponded to very light infec-

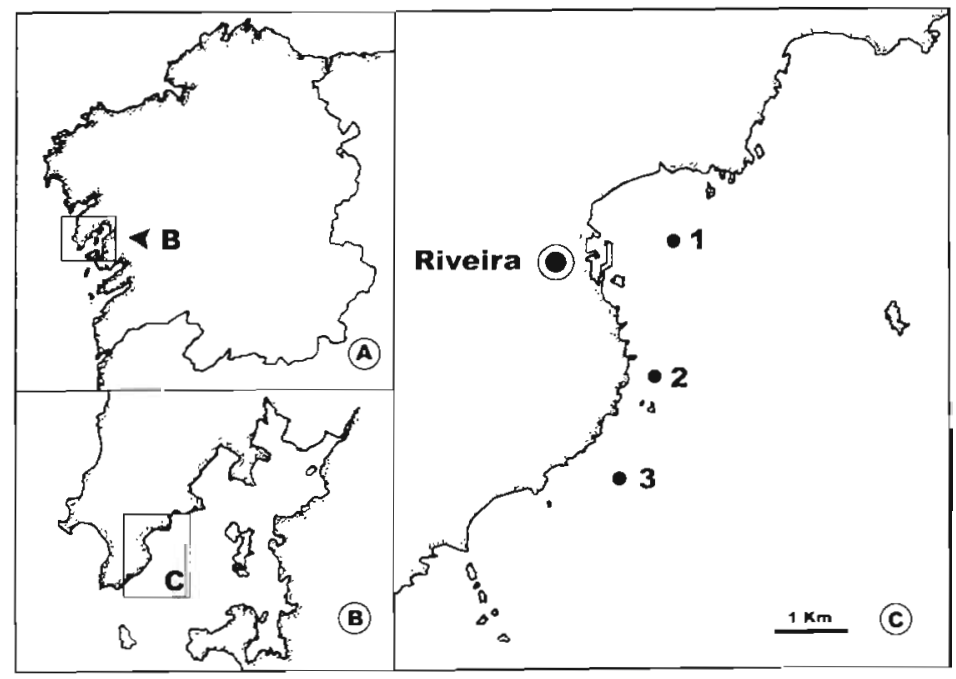

Fig. 1. Galicia (A), Ría de Arousa (B), Ensenada de Riveira (C), Spain, showing locations of sampled clam beds. (1) Coroso, (2) Airós, (3) Agudos 
Table 1. Venerupis rhomboides and Venerupis pullastra. Number of live individuals and number of empty shells in samples, mortality (percentage of empty shells in samples), and size (mean \pm SE) of clams used for histopathological analysis. Only $V$. rhomboides was sampled, except at Airós in September, when $V$. pullastra was sampled as a reference. Agudos was used as the non-affected reference site

\begin{tabular}{|c|c|c|c|c|c|c|c|c|}
\hline & \multicolumn{4}{|c|}{ April 1996} & \multirow[b]{2}{*}{ Coroso } & \multicolumn{2}{|c|}{ - September 1996} & \multirow{2}{*}{ Agudos } \\
\hline & Coroso & $\begin{array}{l}\text { Airós } \\
\text { (Adult) }\end{array}$ & $\begin{array}{l}\text { Airós } \\
\text { (Seed) }\end{array}$ & Agudos & & $\begin{array}{c}\text { Airós } \\
\text { (V.rhomboides })\end{array}$ & $\begin{array}{c}\text { Airós } \\
\text { (V. pullastra) }\end{array}$ & \\
\hline Live individuals & 56 & 278 & 14 & 61 & 86 & 66 & 221 & 49 \\
\hline Empty shells & 33 & 180 & 7 & 2 & 34 & 22 & 24 & 5 \\
\hline Mortality $(\%)$ & 37 & 39 & 33 & 3 & 28 & 25 & 10 & 9 \\
\hline Mean size $(\mathrm{mm})$ & $44.6 \pm 0.95$ & $44.9 \pm 1.20$ & $22.6 \pm 1.21$ & $50.0 \pm 1.33$ & $46.9 \pm 1.30$ & $48.8 \pm 1.18$ & $43.5 \pm 0.57$ & $50.7 \pm 1.44$ \\
\hline
\end{tabular}

tions (intensity 1) and 2 to light infections (intensity 2). Prevalences are given in Table 2.

\section{Histopathology}

Examination of histological sections revealed the occurrence of spherical to elongated basophilic inclusions, 12 to $25 \mu \mathrm{m}$ long, in cells of the basal part of gill filaments of most of the sampled clams (Fig. 2). These inclusions consisted of numerous prokaryotes that were identified as rickettsia-like by TEM (Figs. 3 to 7). Some areas of the gills of infected clams showed inflammatory reaction (Fig. 8), which was probably evoked after lysis of infected cells and release of the prokaryotes and involved disorganisation of branchial architecture. The prevalence of the branchial rick- ettsia-like organisms was high in every sample except in that of Venerupis pullastra from Airós (Table 2). Fig. 9 shows the distribution of clams of each sample according to intensity of infection by branchial rickettsia-like prokaryotes. Clams of the reference samples ( $V$. rhomboides from Agudos and $V$. pullastra from Airós) for both April and September showed the lowest infection intensities. Most of reference clams possessed infection intensities lower than 3 colonies per gill plica section. The highest infection intensities were found in $V$. rhomboides from Airós (up to 51 colonies in a gill plica were counted). Clams from Coroso showed intermediate burdens (Fig. 9). Intensity differences among samples were significant according to the Kruskal-Wallis test $(H=74.5$; $\mathrm{df}=7 ; \mathrm{p}=0.000)$. Paired comparisons disclosed significant differences between $V$. rhomboides from Airós and those from the reference

Table 2. Venerupis rhomboides and Venerupis pullastra. Prevalence of various parasites found in histological sections of sampled clams (\%). Values for the Perkinsus-like parasite based on results of the FTM (fluid thioglycollate medium) test. (-) Not detected

\begin{tabular}{|c|c|c|c|c|c|c|c|c|}
\hline & \multicolumn{4}{|c|}{ - April $1996-$} & \multirow[b]{2}{*}{ Coroso } & \multicolumn{2}{|c|}{ September 1996} & \multirow[b]{2}{*}{ Agudos } \\
\hline & Coroso & $\begin{array}{l}\text { Airós } \\
\text { (Adult) }\end{array}$ & $\begin{array}{l}\text { Airós } \\
\text { (Seed) }\end{array}$ & Agudos & & $\begin{array}{c}\text { Airós } \\
\text { (V.rhomboides) }\end{array}$ & $\begin{array}{c}\text { Airós } \\
(V \cdot \text { pullastra })\end{array}$ & \\
\hline $\begin{array}{l}\text { Branchial rickettsia- } \\
\text { like organisms }\end{array}$ & 96 & 90 & 92 & 76 & 92 & 100 & 8 & 100 \\
\hline $\begin{array}{l}\text { Rickettsia-like organisms } \\
\text { in digestive gland }\end{array}$ & 8 & 10 & 28 & 12 & 12 & 24 & 16 & 32 \\
\hline Branchial large cysts & 76 & 90 & 72 & 72 & 68 & 88 & 16 & 92 \\
\hline Haplosporidian-like plasmodia & 68 & - & - & - & 12 & 4 & 4 & - \\
\hline Microsporidian-like sporoblasts & - & - & 7 & - & - & - & - & - \\
\hline Perkinsus-like parasite (FTM) & 8 & - & 33 & 4 & 80 & 40 & 4 & 48 \\
\hline Unidentified gregarine & 4 & 10 & 20 & 16 & 56 & 56 & 32 & 28 \\
\hline Nematopsis sp. & 100 & 50 & 92 & 92 & 96 & 100 & 44 & 96 \\
\hline Pseudoklossia-like coccidian & 4 & 20 & - & - & - & 16 & - & - \\
\hline Marteilia-like paramyxean. & - & - & 7 & - & - & - & - & - \\
\hline Branchial ciliates & 32 & 20 & 28 & - & 8 & 8 & 8 & 12 \\
\hline Ciliates in digestive gland & - & - & - & - & - & - & 40 & - \\
\hline Paravortex-like turbellarian & 4 & 10 & 13 & 24 & 20 & 24 & 6 & 12 \\
\hline Larval trematodes & 12 & - & - & 4 & 12 & 8 & - & - \\
\hline Unidentified copepods & 40 & 60 & 60 & 20 & 20 & 44 & 44 & 24 \\
\hline
\end{tabular}




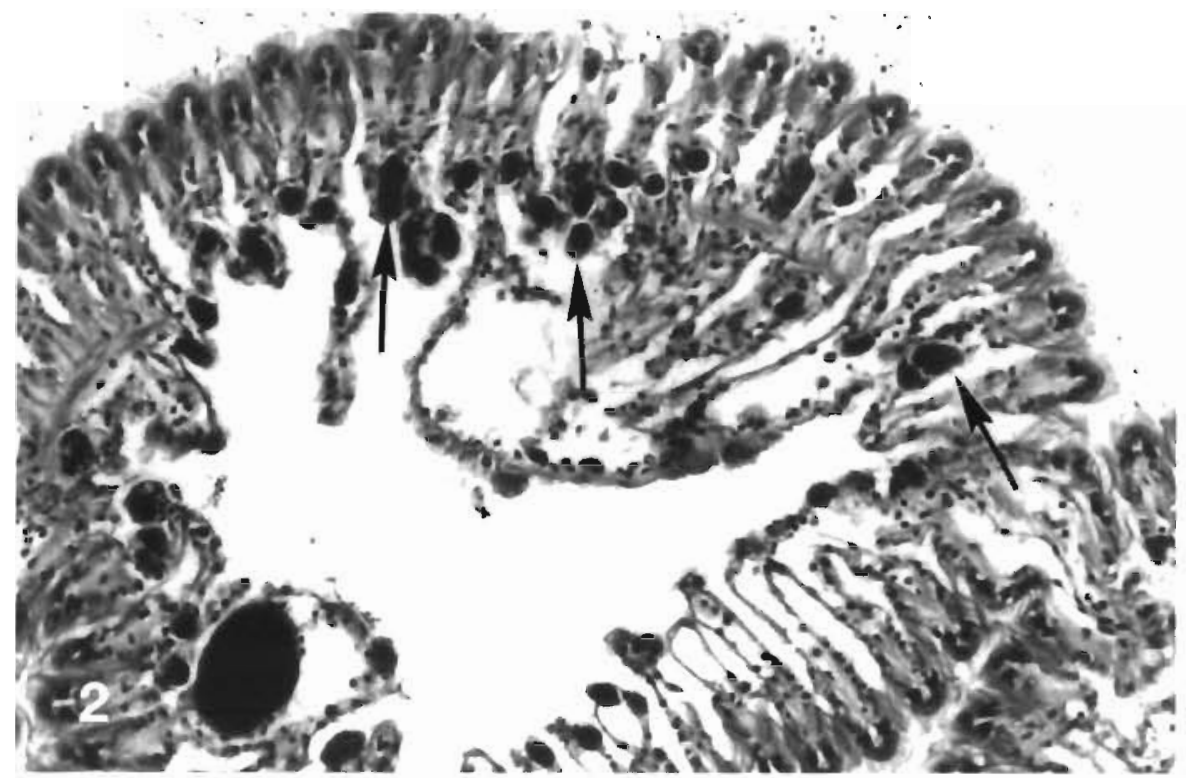

Fig. 2. Venerupis rhomboides. Section through a gill plica showing abundant basophilic inclusions (arrows) (Harris' hematoxylin and $\operatorname{eosin}[\mathrm{HHE}], \times 260)$

sites, both in April and September. Burden differences between clams from Coroso and reference sites were significant only in some cases (Table 3 ).

Additionally, extracellular large cysts (up to $250 \mu \mathrm{m}$ in diameter) surrounded by a thick eosinophilic wall and enclosing anucleated basophilic micro-organisms ( 2 to $4 \mu \mathrm{m}$ in length) were seen attached to the epithelium of gill water tubes, (Fig. 10). These cysts were not found in the material processed for electron microscopy and, therefore, could not be characterised at the ultrastructural level.

Other parasites were detected in clam tissues with low infection intensities. Their prevalences are shown in Table 2. Rickettsia-like inclusions were observed in cells of digestive diverticula. Haplosporidian-like plasmodia occurred in digestive duct epithelia with no obvious damage to the host. Refringent, eosinophilic, spherical spores (ca 2 to $3 \mu \mathrm{m}$ in size), both free and within plasmodia, resembling those of the Microsporidians were observed associated with local disruption of gastric epithelium. Gamonts of an unidentified gregarine occurred in intestinal epithelium with no obvious pathogenic effect. Oocysts of Nematopsis sp. were found inside haemocytes in different organs.
Gamonts of a Pseudoklossia-like coccidian were detected in renal epithelium without noticeable damage. Early stages of infection by a Marteilia-like paramyxean were observed in gastric epithelium. Unidentified ciliates were observed in the lumina of digestive diverticula and gills. Paravortex-like turbellarians were detected in digestive lumina with no pathogenic effect. Heavy infections by trematode sporocysts and cercariae were found occasionally, causing important destruction of host tissues. Unidentified copepods were observed in digestive lumina and gills. No Perkinsus-like parasite was found in the histological sections

\section{Ultrastructural observations}

The branchial rickettsiae-like organisms were densely packed within a parasitophorous vacuole (Fig. 3). They ranged from 1 to $3 \mu \mathrm{m}$ in length and 0.5 to $0.8 \mu \mathrm{m}$ in diameter, with a thin Gram-negative cell wall, electron-dense peripheral cytoplasm and a typical prokaryote nucleoid (Figs, 4 to 6). In favourable longitudinal sections, the rickettsia-like organisms exhib-

Figs. 3 to 7. Branchial rickettsia-like organisms in Venerupis rhomboides. Fig. 3. Ultrathin section of a rickettsia-like colony ( $*$ ). Host cells show numerous microvilli (Mv) and areas where the latter are disorganised (arrows, lower left). In some sections several dense bodies $(\mathrm{Db})$ appeared $(\times 5800)$. Fig. 4 . Ultrathin section of some rickettsia-like prokaryotes showing the wall, cell membrane and the nucleoid $(\mathrm{NC})(\times 32000)$. Fig. 5. Ultrastructural details of a rickettsia-like prokaryote with an elongated nucleoid (arrows), suggesting the beginning of binary fission $(\times 20000)$. Fig. 6 . Ultrastructural details of some rickettsia-like prokaryotes, one of which (决) shows 2 nucleoids. The cell is in the process of binary fission. Host cell shows signs of ly sis (arrows) $(\times 16000)$. Fig. 7. Ultrathin section showing a rickettsia-like colony (*), disruption (arrows) of the parasitophorous vacuole, host cell lysis and release of the prokaryotes $(\times 6700)$ 


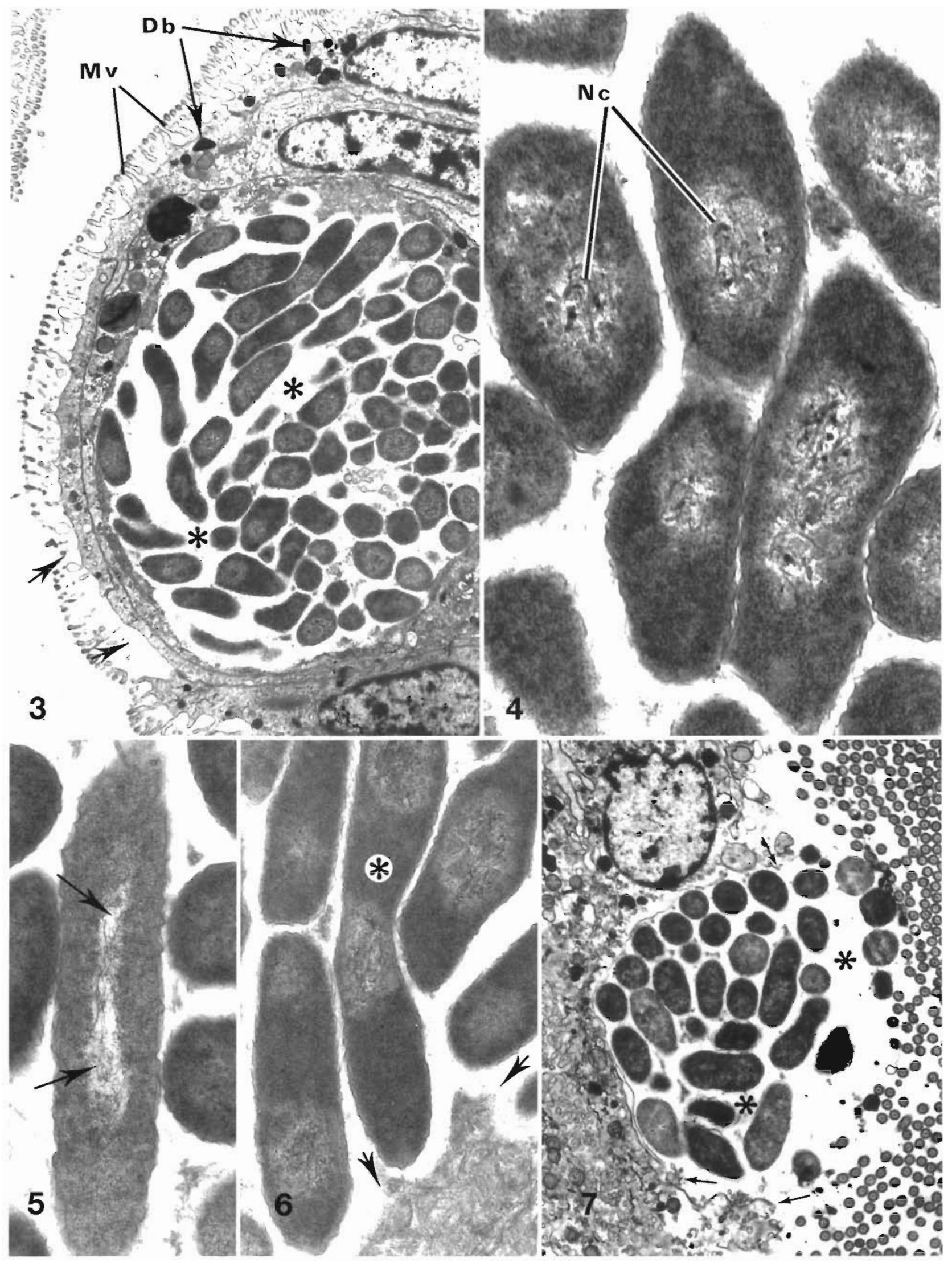




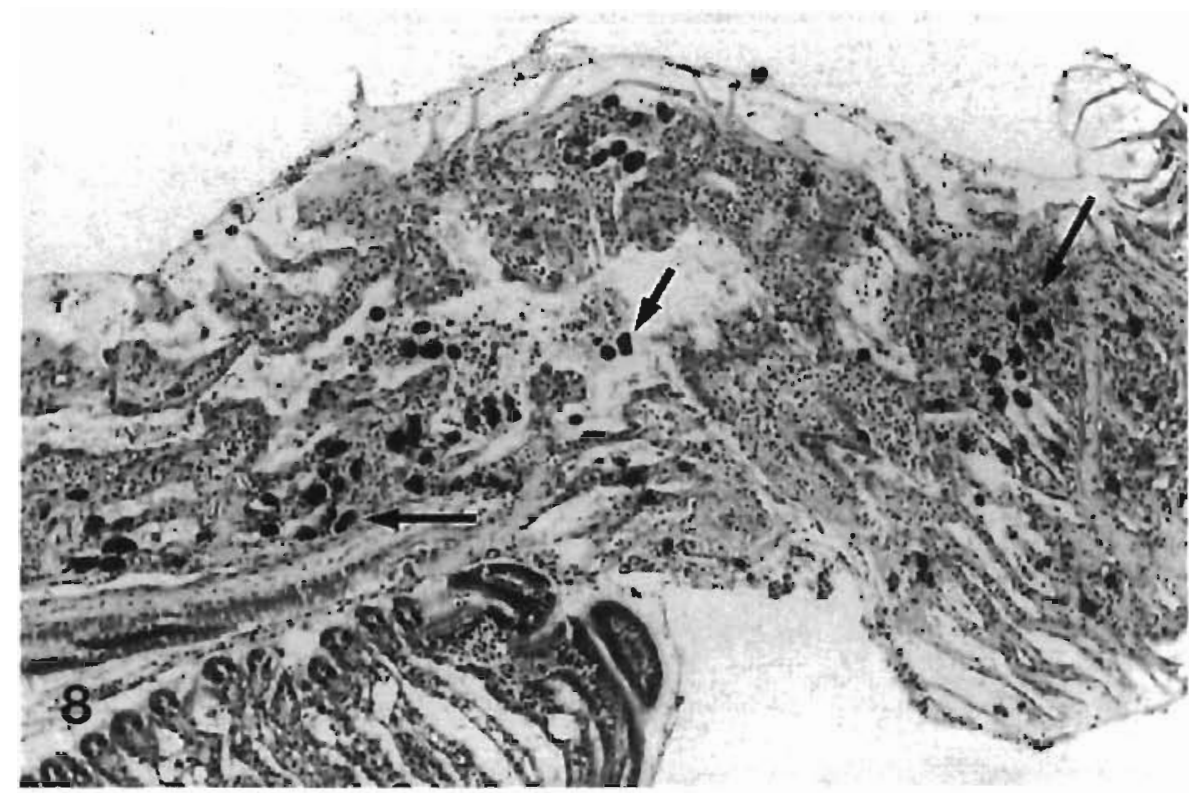

Fig. 8. Venerupis rhomboides. Section through the gills of a clam showing the occurrence of numerous rickettsia-like colonies (arrows). haemocytic infiltration, and disorganisation of branchial architecture $(\mathrm{HHE}, \times 115)$

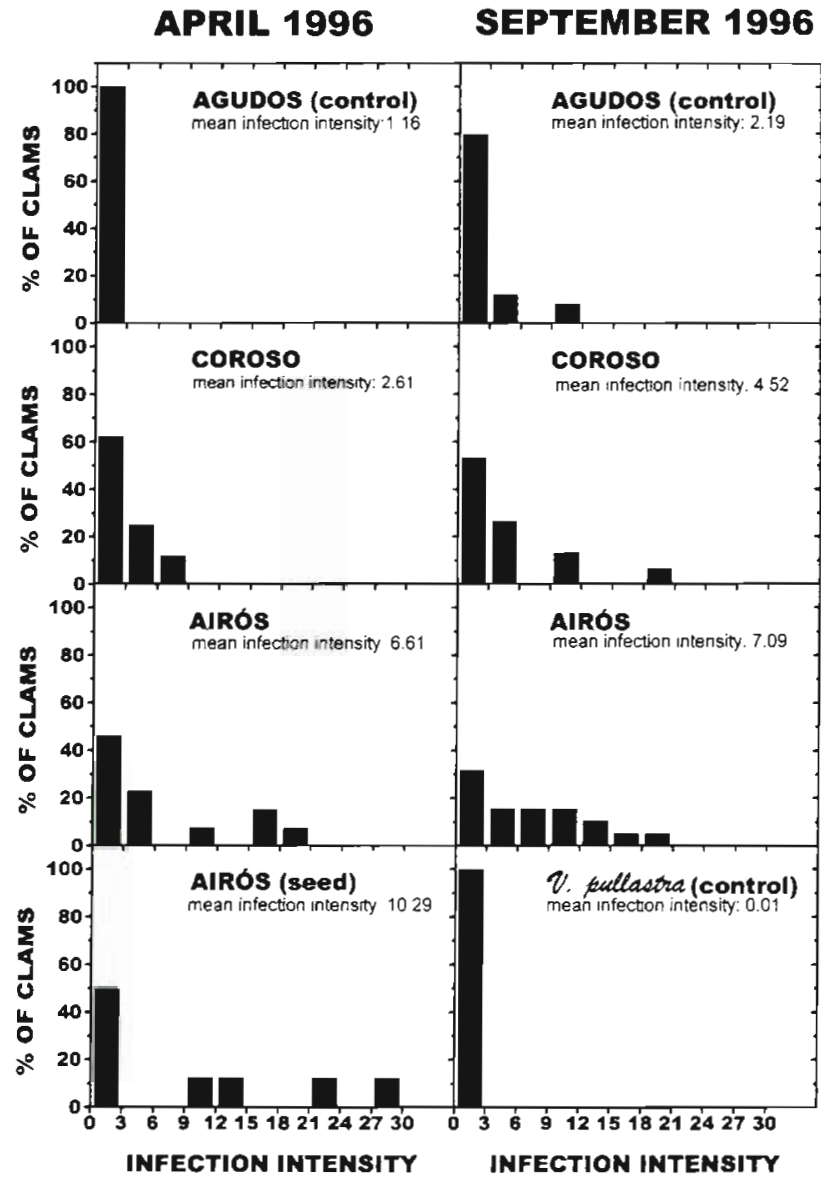

Fig. 9. Venerupis rhomboides. Distribution of the clams of each sample into classes, using 3.0 units as a class interval, according to intensity of infection by branchial rickettsia-like organisms. Mean infection intensity corresponding to each sample $(\mathrm{n}=25)$ is also shown ited a transverse constriction suggesting binary fission (Figs. 5 \& 6). In these cases, an electron-lucent zone containing some dense filament structures was observed on either side of the constriction (Fig. 6). Some infected cells showed accumulation of electron-dense particles, disorganisation of the microvilli (Fig. 3) and pycnotic nuclei. In advanced stages of lysis, disruption of plasmalema and release of the rickettsia-like organisms were observed (Fig. 7).

\section{DISCUSSION}

Percentages of dead clams in samples confirmed a higher mortality in Venerupis rhomboides populations of Airós and Coroso than at the reference site, as the fishermen had claimed. The main objective of this study was to determine if one of more of the types of parasites detected could be responsible for the mortality. There are very few reports of pathological conditions affecting $V$. rhomboides; therefore there have been few parasitological studies. This makes it difficult to determine its normal parasitic fauna. Nevertheless, most of the parasites detected in this study had been previously found in Galician populations of this bivalve mollusc (Villalba et al. 1993). The following criteria would have to be met in order for any of the parasites found in the study to be considered as the cause of the mortality: (1) infection of a high percentage of clams in the areas affected by mortality, (2) development of infections intense enough to cause severe damage to the host, including death, and (3) development of lighter infections (or even absence) in areas without remarkable mortality, that is to say, reference areas. 
Table 3. Venerupis rhomboides and Venerupis pullastra. Results of paired comparisons of the intensity of branchial rickettsia-like infection between samples performed by means of Mann-Whitney test. $n s: p>0.05 \cdot 0.05>p>0.01 . \cdot 0.01>p>0.001 . \cdot{ }^{*} p<0.001$

\begin{tabular}{|c|c|c|c|c|c|c|c|c|}
\hline & \multicolumn{4}{|c|}{$\longrightarrow$ April 1996} & \multirow[b]{2}{*}{ Coroso } & \multicolumn{2}{|c|}{ September 1996} & \multirow{2}{*}{ Agudos } \\
\hline & Coroso & $\begin{array}{l}\text { Airós } \\
\text { (Adult) }\end{array}$ & $\begin{array}{l}\text { Airós } \\
\text { (Seed) }\end{array}$ & Agudos & & $\begin{array}{c}\text { Airós } \\
\text { (V.rhomboides) }\end{array}$ & $\begin{array}{c}\text { Airós } \\
(V . \text { pullastra })\end{array}$ & \\
\hline \multicolumn{9}{|l|}{ April } \\
\hline \multicolumn{9}{|l|}{ Coroso } \\
\hline Airós (adults) & ns & & & & & & & \\
\hline Airós (seed) & $\cdot$ & ns & & & & & & \\
\hline Agudos & ns & $\because$ & $\cdot$ & & & & & \\
\hline \multicolumn{9}{|l|}{ September } \\
\hline Coroso & ns & ns & ns & $\cdot$ & & & & \\
\hline Airós ( $V$. rhomboides) & $\cdots$ & ns & ns & $\cdots$ & ns & & & \\
\hline Airós ( $V$. pullastra) & $\cdots$ & $\cdots$ & $\cdots$ & $\cdots$ & $\cdots$ & $\cdots$ & & \\
\hline Agudos & ns & : & $\cdot$ & ns & ns & $\cdots$ & $\cdots$ & \\
\hline
\end{tabular}

According to the results from samples from the 2 sampling periods, only branchial rickettsia-like infection approached fulfillment of the 3 requirements. Their prevalence was high and the infection intensity was heavy in many of the clams in the areas affected by mortality, whereas prevalence and, mainly, infection intensity were lower in reference populations. Histological and cytological signs of pathogenicity were observed, although the ability of branchial rickettsiae to develop lethal infections in Venerupis rhomboides must be further tested. Nevertheless, there are precedents of mass mortalities of razor clams Siliqua patula (Elston 1986), scallops Pecten maximus (Le Gall et al. 1991), giant clams Hippopus hippopus (Norton et al. 1993), and, to a lesser extent, sea scallops Placopecten magellanicus (Gulka \& Chang 1984) caused by branchial rickettsiae.
Other parasites found in the samples are known to cause severe damage to the host. Parasites of the genus Perkinsus were blamed for mortalities in the clam Ruditapes decussatus in Venice Lagoon (NE Italy) (Breber 1985) and Algarve (S. Portugal) (Azevedo 1989). However, the Perkinsus-like parasite detected in samples of the present study cannot be blamed for the mortality since the infections were very light in each sampled population. Heavy infections by trematodes were observed, but they cannot be considered to be responsible for high mortality because of their very low prevalence. Similarly, the very low prevalence of infections by the Marteilia-like paramyxean and the microsporidian-like parasite indicates that they were not involved in the mortalities studied, despite their potential for causing disease. The other parasites found are not known to cause lethal infections.
Fig. 10. Venerupis rhomboides. Section through a gill plica showing large cysts $(\star)$ enclosing anucleated basophilic micro-organisms and surrounded by a thick wall (arrows) $(\mathrm{HHE}, \times 230)$

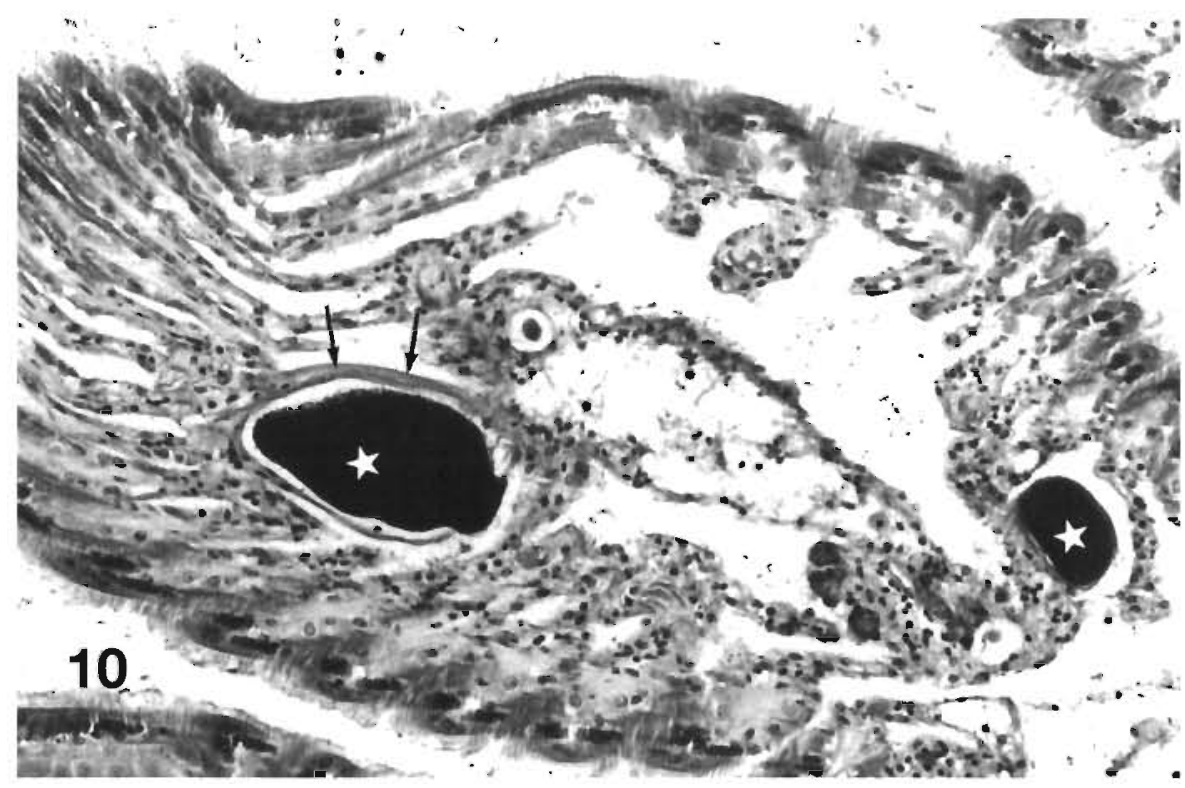


Intracytoplasmic basophilic inclusions very similar to the rickettsial colonies described here have been found in the clams Ruditapes decussatus and Venerupis pullastra from other Galician zones (Villalba et al. 1993) without association with important mortalities. Likely, gill function is seriously compromised only when infection intensity is heavy. Results showed that branchial rickettsial infection can affect juvenile clams, as in the case of the scallop Pecten maximus (Le Gall et al. 1991).

Samples of Venerupis rhomboides taken in April 1996 from Airós were analysed to estimate contents of faecal coliform and Vibrio bacteria, heavy metals, PCBs and pesticides by the staff of the Centro de Control da Calidade do Medio Mariño. Results of the analyses were within normal limits (Consellería de Pesca, Marisqueo e Acuicultura, internal reports) therefore, pollution is not considered to be responsible for the mortality.

The ultrastructural morphology of the prokaryotes inside the branchial intracytoplasmic colonies resembles that of other Rickettsia-like organisms previously reported in different bivalve molluscs (Harshbarger et al. 1977, Comps 1983, Fries \& Grant 1991). Prokaryotes infecting gills of various bivalve species have been determined to be rickettsia-like according to ultrastructural characters (Gulka \& Chang 1984, Elston 1986, Mialhe et al. 1987, Le Gall et al. 1988, Goggin \& Lester 1990, Azevedo \& Villalba 1991, Fries \& Grant 1991, 1992 Fries et al. 1991, Norton et al. 1993, Renault \& Cochennec 1994, Wen et al. 1994). Morphological characters hardly permit separation of the various rickettsia-like organisms found in bivalve molluscs. Histological location, colony morphology and ultrastructural features (including nucleoid aspect and figures of binary fission) are very similar between the branchial rickettsiae of Venerupis rhomboides and those of the closely related clam Ruditapes decussatus described by Mialhe et al. (1987). Those authors reported the occurrence of scarce hypertrophic colonies $(100 \mu \mathrm{m})$ in addition to the more abundant small prokaryotic colonies. Those larger colonies found in $R$. decussatus could be equivalent to the large cysts enclosing anucleated basophilic microorganisms observed in $V$. rhomboides. Le Gall et al. (1988) also observed the occurrence of small colonies, containing only a few rickettsiae, and large colonies, which obstructed the blood spaces, in the gills of the sea scallop Pecten maximus.

Acknowledgements. Members of the Confraría de Pescadores de Riveira helped in sampling of clarn beds. Ms. Elena Penas Ms. Maribel Meléndez, Ms. Pilar Iglesias and Ms. Ana Maria Ozón provided technical assistance with histological techniques, and Mr. Joao Carvalheird with iconographic figures. This study was partially supported by Engeneiro A. Almeida Foundation (Porto)

\section{LITERATURE CITED}

Azevedo C (1989) Fine structure of Perkinsus atlanticus n. sp. (Apicomplexa, Perkinsea), parasite of the clam Ruditapes decussatus from Portugal. J Parasitol 75:627-635

Azevedo C, Villalba A (1991) Extracellular giant rickettsiae associated with bacteria in the gill of Crassostrea gigas (Mollusca, Bivalvia). J Invert Pathol 58:75-81

Breber P (1985) On-growing of the carpet-shell clam (Tapes decussatus (L.)): two years' experience in Venice Lagoon. Aquaculture 44:51-56

Comps M (1983) Recherches histologiques et cytologiques sur les infections intracellulaires des mollusques bivalves marins. Thèse de Doctorat d'Etat, Université des Sciences et Téchniques du Languedoc, Montpellier

Elston RA (1986) An intranuclear pathogen [nuclear inclusion $X$ (NIX)] associated with massive mortalities of the Pacific razor clam, Siliqua patula. J Invert Pathol 47:93-104

Fries CR, Grant DM (1991) Rickettsiae in gill epithelial cells of the hard clam Mercenaria mercenarja. J Invert Pathol 57: $166-171$

Fries CR, Grant DM (1992) Erlichia-like microorganisms in hemocytes in the gills of the marine bivalve, Mercenaria mercenaria. J Invert Pathol 59:210-211

Fries CR, Grau SB, Tripp MR (1991) Rickettsize in the cytoplasm of gill epithelial cells of the soft-shelled clam, Mya arenaria. J Invert Pathol 57:443-445

Goggin CL, Lester RJG (1990) Rickettsiales-like infection in the gills of Tridacna crocea from the Great Barrier Reef. J Invert Pathol 56:135-138

Gulka G, Chang PW (1.984) Pathogenicity and infectivity of a rickettsia-like organism in the sea scallop. Placopecten magellanicus. J Fish Dis 8:309-318

Harshbarger JC, Chang SC, Otto SV (1977) Chlamydiae (with phages), mycoplasms and rickettsiae in Chesapeake Bay bivalves. Science 196:666-668

Le Gall G, Chagot D, Mialhe E, Grizel H (1988) Branchial rickettsiales-like infection associated with a mass mortality of sea scallop Pecten maximus. Dis Aquat Org 4:229-232

Le Gall G, Mialhe E, Chagot D. Grizel H (1991) Epizootiological study of rickettsiosis of the Saint-Jacques scallop Pecten maximus. Dis Aquat Org 10:139-145

Mackin JG (1962) Oyster disease caused by Dermocystidium marinum and other microorganisms in Louisiana. Publ Inst Mar Sci Univ Tex 7:132-299

Mialhe E, Chagot D, Boulo V. Comps M, Ruano F, Grizel H (1987) An infection of Ruditapes decussatus (Bivalvia) by Rickettsia. Aquaculture 67:258-259

Norton JH, Shepherd MA, Abdon-Naguit MR, Lindsay S (1993) Mortalities in the giant clam Hippopus hippopus associated with rickettsiales-like organisms. J Invert Pathol 62:207-209

Ray SM (1966) A review of the culture method for detecting Dermocystidium marinum, with suggested modifications and precautions. Proc Natl Shellfish Assoc 54:55-69

Renault $T$, Cochennec N (1994) Rickettsia-like organisms in the cytoplasm of gill. epithelial. cells of the Pacific oyster Crassostrea gigas. J Invert Pathol 64:160-162

Villalba A, López MC, Carballal MJ (1993) Parásitos y alteraciones patológicas de tres especies de almeja, Ruditapes decussatus, Venerupis pullastra y Venerupis rhomboides, en las rias gallegas. In: Cervino A, Landín A, de Coo A, Guerra A, Torre $M$ leds) Actas del IV Congreso Nacional de Acuicultura, Centro de Investigacións Marinas, Vilagarcía de Arousa, p 551-556

Wen CM, Kou GH, Chen SN (1994) Rickettsiaceae-like microorganisms in the gill and digestive gland of the hard clam. Meretrix lusoria Röding. J Invert Pathol 64:138-142

Submitted: February 4, 1998; Accepted: December 11, 1998 Proofs received from author(s): March 2, 1999 